\title{
The Impact of Intellectual Capital on Firm Financial Performance by Moderating of Dynamic Capability
}

\author{
Majid Dadashinasab ${ }^{1} \&$ Saudah Sofian ${ }^{1}$ \\ ${ }^{1}$ Department of Accounting and Finance, Faculty of Management, Universiti Teknologi Malaysia, Skudai Johor, \\ Malaysia \\ Correspondence: Majid Dadashinasab, Department of Accounting and Finance, Faculty of Management, \\ Universiti Teknologi Malaysia, Skudai Johor, Malaysia. E-mail: Majiddadashinasab@gmail.com
}

Received: May 22, 2013 Accepted: July 4, 2014 Online Published: August 20, 2014

doi:10.5539/ass.v10n17p93 URL: http://dx.doi.org/10.5539/ass.v10n17p93

\begin{abstract}
The purpose of this study is to investigate empirically the effect of intellectual capital (IC) on high IC firm financial performance with moderating role of dynamic capability (DC). The period covered is from 2000 to 2011. Secondary data were collected from financial statements of high IC firms of Malaysia (technology sector, consumer products sector, trading and service sector, and industrial products) obtained from their websites. Regression models were developed to test the relationship among firm financial performance and IC. The analysis findings indicate that, the impact of IC on firm financial performance increases when DC is included as moderator. In addition, there is positive and significant relationship between humane capital efficiency (HCE), structural capital efficiency (SCE), and capital employed efficiency (CEE) with firm financial performance.
\end{abstract}

Keywords: intellectual capital (IC), high IC firm financial performance, dynamic capability

\section{Introduction}

During the industrial age, tangible assets, labor and financial capital were considered the organization's resources of wealth (Gan \& Saleh, 2008). After the shift of market environment from the industrial period to the information period (Hsu \& Wang, 2012), IC which is also known as intangible assets, is considered as the fourth factor of production, in addition to financial capital, labor and land (Lev \& Daum, 2004).

Emphasizing the performance of knowledge based firms such as Microsoft is indicated in the power of market value rather than the book value of these firms (Sullivan, 1999). There is a big gap among a company's book value and its market value, the reasons of this gap is intangible assets (Sullivan, 1999). Some of the intangible assets in the firms are recognized and reported in the financial statements of firms such as brand equity and patents. In contrast, latent intangibles, for instance, skills and experience of employees, relationships, databases and information and administration system do not have formal categorization for recognition. However, they strongly contribute to organization's market value. IC has been identified as intangible assets among researchers and regulators, resulting in its recognition in firms annual reports or disclosed as separate reports (Stewart, 1997). Balance sheet (now is known as statement of financial position) only discloses physical assets of firms with historical and book value, and it does not indicate IC as a significant part of firms' total value. Thus original value of firms is not illustrated by financial statement. Therefore, disclosing and identifying IC is one of the important issues that firms attempt to depict in their financial statement beyond traditional financial accounting standards (Mouritsen, 2003).

Today, one of the important resources for increasing firm performance is IC (Itami \& Roehl, 1991). The strong relationship between the market tendency and performance was discovered by Jaworski and Kohli (1993). Organizations can be successful if they indicate and manage their IC (Nonaka \& Takeuchi, 1995).

The aim of the study was: first, to survey the effect of IC on firm financial performance in high IC firms of Malaysia, secondly, was to test the moderating effect of dynamic capability (DC) on this relationship. 


\section{Literature Review}

\subsection{Intellectual Capital (IC)}

There is a wide range of definitions for IC in the literature. One of the important steps that could help organizations achieve profitability is effective management of IC, yet finding its definition is difficult (Fondo \& Wright, 2004). Definitions of IC focus on different items that can help create value in firms (Stewart, 1997) such as human properties, to organizational properties and knowledge (Mouritsen, 1998). In recent decades, there have been many attempts to find a standard definition of IC and acceptable definition by many researchers. Thomas Stewart has written the first concept of IC in a business journal in 1991 in an article for Fortune magazine (Stewart, 2001). Stewart (1991)suggested that if firms want to indicate intangible assets, they can disclose them in the financial statement like other assets. Stewart (1991) defined IC as the "sum of everything everybody in your company knows that gives you a competitive edge in the marketplace".

In this study, presented definition by Edvinsson and Malone (1997) is considered as the operational definition. This is because value added IC coefficient method (VAIC) which will be employed for measuring IC (that will be discussed in later sections) is according to the Skandia Navigator model, and this model is based on the definition and categorization of Edvinsson and Malone (1997). According to this definition, IC is divided in to human capital (H C) and structural capital (SC).

Sveiby (1989) considered structural capital and individual capital as parts of IC which is also known as a know-how capital. Individual and public abilities, experience, competence and skills of firm's employees have named individual capital. Firm's competence is named structural capital which includes administration and computer system, edge and experience of firms and data bases. Skandia (1994) indicates that IC consists of both $\mathrm{HC}$ and $\mathrm{SC}$ which are parts of the aggregate sum of intangible value.

Generally, scholars divided IC into three main parts. According to the definition by Bontis (1999), Edvinsson and Malone(1997), Stewart (1991, 1997), HC, SC and RC are parts of IC.

\subsection{Dynamic Capability (DC)}

DC is indirectly defined as an ability to create and reconfigure the resources to adapt rapidly changing markets, but one of the best and comprehensive definitions of DC is presented by Wang and Ahmad (2007). According to their definition, DC is the orientation stable behavior of firms to renew, integrate, recreate and reconfigure their capabilities and resources, and reconstruct and upgrade their core capabilities in response to the dynamic market to sustain competitive advantage. This definition is considered as the operational definition of this study because it includes DC and IC (DC is ability of firm to renew, integrate, recreate and reconfigure their capabilities and resources), and effect of DC on performance (DC reconstruct and upgrade firms core capabilities in response to the dynamic market to sustain competitive advantage and to sustain performance).

\section{Conceptual Framework and Hypotheses}

\subsection{IC and Performance}

Youndt (1998) studied the relationships between SC, HC, and RC as parts of IC, on the one hand, and sales growth, financial returns, organizational costs and customer benefits as parts of performance on the other. His research results are:

- The positive relationship among $\mathrm{HC}$ and sales growth and significant relationship between $\mathrm{HC}$ and increasing customer benefits, but financial returns, reducing organizational costs are not significantly related.

- The negative relationship among RC and sales growth and significant relationship between RC and reducing organizational costs, but financial returns and increasing benefits are not significantly related.

- The positive relationship among SC and financial returns and increasing customer benefits, but sales growth, reducing organizational cost are not significantly related.

Firer and Williams (2003) conducted a study about relationship between traditional financial performance and intellectual capital which was measured by VAIC method. The findings of this research revealed that there were no positive and significant association among profitability, productivity, and market value as dependent variables and three components of IC. These results indicate that they depended mostly on their tangible resources.

Chan (2009a) conducted a study in Hong Kong. He stated there was no significant relationship between financial performance and IC of firm. ROA, MB, ROE and ATO are used for measuring financial performance. This study was lasted from 2001 to 2005 . The important of physical capital was one of the main results of this study. On the 
other hand, according to results of this research, one of the most important factor for improving market valuation, productivity, and profitability of the firms is physical capital.

One of the obvious effects of IC was the increasing competitive advantage and logically was the increasing in performance of firm. There were many studies to survey association among IC and performance, and its literature. The current paper made an attempt to enrich the literature of IC, thus, hypothesizing:

H1: IC has a significant and positive impact on high IC firm financial performance.

H1a: HCE has a significant and positive impact on high IC firm financial performance.

H1b: SCE has a significant and positive impact on high IC firm financial performance.

H1c: CEE has a significant and positive impact on high IC firm financial performance.

\subsection{IC, DC, and Firm Financial Performance}

There are many literatures on IC and improvement of organizations performance. Investigating the moderating impact of dynamic capability on the association among IC and financial performance is the purpose of this research. The literature on the relationship between dynamic capability and components of IC is scant, but there are conceptual reasons to expect this association. This association is generated in order to respond to the question why and how some organizations appear to sustain and create competitive advantage.

Additionally, based on the dynamic perspective, sustaining stable firm performance depends on competitive and consistent behavior that relies on the firm ability to adapt and learn. This is possible if IC is exploited and developed through DC (Hsu \& Wang, 2012). Wang and Ahmad (2007) defined DC as the firm orientation stable behavior to renew, integrate, recreate and reconfigure their capabilities and resources. Reconstructing and upgrading their core capabilities in response to the dynamic market are considered essential to sustain competitive advantage. IC is also known as knowledge resources that can be transformed into value and profit. Therefore, it is the firm's stable behavior that can renew, integrate and reconfigure its IC to sustain competitive advantage and further earn high performance.

Some previous researchers such as Hsu and Fang (2009), Kamukama et al. (2011), and Chen et al. (2006) believed in the need to employ a moderating or mediating variable on the association among VAIC and financial performance. For example, Kamukama et al. (2011) used competitive advantage as a mediating variable on the relationship among IC and firm performance. The result of the research showed that the relationship was significantly mediated by competitive advantage. Therefore, as pointed by the above discussion, this research seeks to survey the moderating effect of DC on the relationship among VAIC and firm financial performance. And the following hypotheses will be tested:

H2: DC moderates the impact of IC on high IC firm financial performance.

H2a: DC moderates the impact of HCE on high IC firm financial performance.

H2b: DC moderates the impact of SCE on high IC firm financial performance.

H2c: DC moderates the impact of CEE on high IC firm financial performance.

\section{Research Method}

\subsection{Sample and Data Selection}

The high IC listed firms on the main board of Bursa Malaysia were the subjects of this research. According to Usoff et al. (2002), high IC firms are normally large in size, and one of the ways to determine size is by looking at the number of employees. Also, based on Sofian (2005), the companies which are expected to have high IC were chosen among the technology sector (mainly rich in HC and SC because of high investment in employee's education and skills, and R\&D activities), consumer products sector (mainly rich in RC because of high investment in customer and suppliers relationships), trading and service sector (mainly rich in $\mathrm{HC}$ and $\mathrm{RC}$ because of high investment in employee's education and skills, and customer and suppliers relationships), and industrial products (mainly rich in $\mathrm{HC}$ and $\mathrm{SC}$ because of high investment in employee's education and skills, and $R \& D$ activities). The period covered were from 2000 to 2011. In addition, Secondary data were collected from financial statements of the firms websites and analyzed.

\subsection{Variables Measurement}

\subsubsection{IC}

In this study the VAIC method which was presented by Pulic (2000a) was be used for measuring IC variables (HC, SC, and CE). 
In this model, the difference between input and output is the value added:

Where, VA = OUT - IN

VA $\quad=$ Value added for the firm

OUT $=$ Total revenues (sales)

IN $=$ Cost of brought- In materials, components and services

\subsubsection{Human Capital Efficiency}

Expenditures on employees are not considered as part of INPUT in VAIC, and expenses related to employees are presented as an investment in this formula.

\subsubsection{Structural Capital Efficiency}

$$
\mathrm{HCE}=\mathrm{VA} / \mathrm{HC}
$$

$\mathrm{SC}$ is the second component of IC which is computed below:

$$
\mathrm{SC}=\mathrm{VA}-\mathrm{HC}
$$

There is no direct measurement method for SC, but it is the residual from VA minus HC. Therefore, SCE is calculated using the following formola:

$$
\mathrm{SCE}=\mathrm{SC} / \mathrm{VA}
$$

Finally, the sum of the partial coefficients of structural and human capital is IC efficiency as shown in the following formula:

\subsubsection{Capital Employed Efficiency}

$$
\mathrm{ICE}=\mathrm{HCE}+\mathrm{SCE}
$$

Pulic (2000a) argued that in order to have a broad picture of efficiency of value creating resources, it is important to take physical and financial capital into consideration. The following formula presents how capital employed efficiency can be obtained:

$$
\mathrm{CEE}=\mathrm{VA} / \mathrm{CE}
$$

Finally, the sum of ICE and CEE indicates overall value creation efficiency:

$$
\mathrm{VAIC}=\mathrm{ICE}+\mathrm{CEE}
$$

\subsubsection{Dynamic Capability Measurement}

According to Hsu and Wang (2012), companies with high investment in R\&D can gain a strategic competitive advantage, and economic value for the firms is continued over time if they have investment in marketing. Therefore, DC creation processes are directly related with R\&D. Thus, in this study, the percentage of increase in $\mathrm{R} \& \mathrm{D}$ deployment is used for measuring DC as shown in the following formula:

$$
\mathrm{DC}=(1 / 2)\left[\left(\frac{\mathrm{R} \& \mathrm{D}_{\mathrm{t}-1}-\mathrm{R} \& \mathrm{D}_{\mathrm{t}-2}}{\mathrm{R} \& \mathrm{D}_{\mathrm{t}-2}}\right)+\left(\frac{\mathrm{R} \& \mathrm{D}_{\mathrm{t}-2}-\mathrm{R} \& \mathrm{D}_{\mathrm{t}-3}}{\mathrm{R} \& \mathrm{D}_{\mathrm{t}-3}}\right)\right.
$$

\subsubsection{Financial Performance Measurement}

In this study, return on assets (ROA) was applied for evaluating financial performance of firm. This ratio was calculated by the following formula (Maditinos, Chatzoudes, Tsairidis, \& Theriou, 2011):

$$
\mathrm{ROA}=\frac{\text { Net Income }}{\text { Total Assets }}
$$

\subsection{Regression models}

Three steps of applying a hierarchical multiple regression to investigate the moderating impact of DC were employed as follows (Frazier, Tix, \& Barron, 2004).

The impact of predictor variables on dependent variable (Model 1):

$$
R O A_{i, t}=\alpha_{0}+\beta_{1} C E E_{i, t}+\beta_{2} H C E_{i, t}+\beta_{3} S C E_{i, t}+\beta_{4} V A I C_{i, t}+\varepsilon_{i, t}
$$

Where $R O A_{i, t}$ is the returen on assets of firm $\mathrm{i}$ in year $\mathrm{t}$, are effective CEE, HCE, SCE, and VAIC. The disturbance term denoted as $\varepsilon i t$ was assumed to be serially uncorrelated with mean zero. 
The impact of moderator variable on dependent variable (Model 2):

$$
R O A_{i, t}=\alpha_{0}+\beta_{1} C E E_{i, t}+\beta_{2} H C E_{i, t}+\beta_{3} S C E_{i, t}+\beta_{4} V A I C_{i, t}+\beta_{5} D C_{i, t}+\varepsilon_{i, t}
$$

Where DC is dynamic capability;

The effect of interaction among the predictor variables and the moderator on dependent variable (Model 3) is calculated using the following formula:

$$
\begin{aligned}
& R O A_{i, t}=\alpha_{0}+\beta_{1} C E E_{i, t}+\beta_{2} H C E_{i, t}+\beta_{3} S C E_{i, t}+\beta_{4} V A I C_{i, t}+\beta_{5} D C_{i, t}+\beta_{5} V A I C D C_{i, t} \\
& +\beta_{7} H C E D C_{i, t}+\beta_{8} S C E D C_{i, t}+\beta_{9} C E E D C_{i, t}+\varepsilon_{i, t}
\end{aligned}
$$

Where VAICDC is interaction of IC efficiency and dynamic capability; HCEDC is interaction of human capital efficiency and dynamic capability; SCEDC is interaction of structural capital efficiency and dynamic capability; CEEDC is interaction of capital employed efficiency and dynamic capability. The disturbance term denoted as Eit was assumed to be serially uncorrelated with mean zero.

\section{Results and Analysis}

Statistical software STATA was employed to analyse the data.

\subsection{Descriptive Statistic and Correlation Analysis}

Table 1. Illustrates the overview of the nature of data analyzed, using the descriptive statistics

\begin{tabular}{cccccc}
\hline Variables & $\mathrm{N}$ & Minimum & Maximum & Mean & Std. Deviation \\
\hline ROA & 1210 & -0.22 & 0.28 & 0.0439 & 0.07440 \\
VAIC & 1210 & -1.74 & 7.25 & 2.4522 & 1.52567 \\
HCE & 1210 & -2.91 & 6.49 & 1.8573 & 1.37380 \\
SCE & 1210 & -1.27 & 2.09 & 0.4582 & 0.41038 \\
CEE & 1210 & -0.40 & 0.94 & 0.2211 & 0.17348 \\
DC & 1210 & -0.93 & 0.94 & 0.0234 & 0.25341 \\
VAICDC & 1210 & -2.05 & 2.27 & 0.0694 & 0.57300 \\
HCEDC & 1210 & -1.64 & 1.41 & 0.0529 & 0.42344 \\
SCEDC & 1210 & -0.43 & 0.42 & 0.0115 & 0.11320 \\
CEEDC & 1210 & -0.15 & 0.15 & 0.0052 & 0.04060 \\
\hline
\end{tabular}

$\overline{\mathrm{ROA}}=$ Return on assets; VAIC $=$ Value added intellectual capital coefficient; HCE = Human capital efficiency; $\mathrm{SCE}=$ Structural capital efficiency; $\mathrm{CEE}=$ Capital employed efficiency; $\mathrm{DC}=$ Dynamic capability; VAICDC $=$ Interaction of Value Added IC Coefficient and dynamic capability; HCEDC = Interaction of human capital efficiency and dynamic capability; SCEDC = Interaction of structural capital efficiency and dynamic capability; $\mathrm{CEEDC}=$ Interaction of capital employed efficiency and dynamic capability;

\subsection{Empirical Results of Multiple Regressions}

Table 2 presents the result of hierarchical multiple regressions related to Models 1,2 and 3. Model 1 is includes ROA as main independent variables (first step). Model 2 includes moderator variables (second step). Model 3 includes the interaction terms (VAICDC, HCEDC, SCEDC, and CEEDC). The F statistic in Model 1 is significant $(\mathrm{F}=127.94, \mathrm{p}<0.000)$, indicating that the CEE, HCE, SCE, and VAIC can be considered to be influencing ROA. Model 1 reveals that HCE, SCE, and CEE have positively and significantly influencing ROA while VAIC is insignificantly and positively (coefficient $=0.003$, p-value $=0.339$ ) effecting ROA. Therefore, it can reasonably be concluded that Hypothesises H1a, H1b, and H1c are accepted, but Hypothesises H1 is rejected.

Model 2 shows that the $\mathrm{F}$ statistic is significant $(\mathrm{F}=106.07, \mathrm{p}<0.000)$, suggesting that $\mathrm{DC}$ can be considered to be effecting financial performance by traditional measures. Model 3 which presents the impact of interaction 
terms (CEEDC, HCEDC, SCEDC, and VAICDC) on ROA has a change in $\mathrm{R}^{2}$ of 0.007 and significant $\mathrm{F}$ change of 0.000 . The $R^{2}$ of 0.420 indicates the strong model explanatory power. In this Model the $F$ statistic is significant $(\mathrm{F}=62.72, \mathrm{p}<0.000)$, indicating that they can be considered to be effecting ROA. In regard to interaction terms (VAICDC, HCEDC, SCEDC, and CEEDC), VAICDC is positively and significantly influencing ROA (coefficient $=0.023$, p-value $=0.002$ ). In contrast HCEDC is negetively and significantly (coefficient $=-0.034$, $p$-value $=0.003$ ) effecting ROA. In addition, SCEDC and CEEDC have insignificant effect on ROA. Therefore, the overall result of Model 3 is supporting Hypothesis $\mathrm{H} 2$ and H2a, but Hypothesis H2b and $\mathrm{H} 2 \mathrm{c}$ are rejected.

Table 2. The result of the least square regression analysis with robust standard errors to examine the effect of VAIC, HCE, SCE, and CEE on ROA, DC as moderator

\begin{tabular}{cccc}
\hline Variables & $\begin{array}{c}\text { Model 1 } \\
\text { Coefficient (p-value) }\end{array}$ & $\begin{array}{c}\text { Model 2 } \\
\text { Coefficient (p-value) }\end{array}$ & $\begin{array}{c}\text { Model 3 } \\
\text { Coefficient (p-value) }\end{array}$ \\
\hline VAIC & $.003(0.334)$ & $0.003(0.339)$ & $0.003(0.419)$ \\
HCE & $0.019(0.000)$ & $0.018(0.000)$ & $0.019(0.000)$ \\
SCE & $0.024(0.001)$ & $0.025(0.000)$ & $0.027(0.000)$ \\
CEE & $0.152(0.000)$ & $0.155(0.000)$ & $0.155(0.000)$ \\
DC & & $0.026(0.000)$ & $0.034(0.004)$ \\
VAICDC & & & $0.023(0.002)$ \\
HCEDC & & & $-0.034(0.003)$ \\
SCEDC & & & $-0.022(0.379)$ \\
CEEDC & & $-0.046(0.000)$ & $0.076(0.066)$ \\
CONS & $-0.046(0.458)$ & 0.413 & $-0.047(0.000)$ \\
$\mathrm{R}^{2}$ & 0.405 & 0.008 & 0.420 \\
Change in $\mathrm{R}^{2}$ & - & $106.07(0.000)$ & 0.007 \\
F-Value (Sig. F) & $127.94(0.000)$ & & $62.72(0.000)$ \\
\hline
\end{tabular}

\section{Discussion of Results}

Findings of this study based on the association among IC and high IC firm financial performance demonstrated that there exists no association among IC and firm financial performance. Therefore, H1 is rejected. The investors place greater value on companies with greater IC but failed to support the hypothesis. The results of the current research offer the bibliography of other research that was unable to support completely to the significance of IC. For example, Chen et al. (2006) founded an association among VAIC and firm financial performance in the Taiwan, while Firer and Williams (2003), in a study carried out on South Africa, failed to explain an association among VAIC and financial performance. On two researchs carried out in Malaysia, Shiu (2006) succeeded in explaning an association among VAIC and financial performance, while Gan and Saleh (2008) failed to explain relationship between VAIC and market valuation, but found the positive association among VAIC, profitability, and productivity. These conflicts could be because of some reasons; first, most of the researchs have been carried out in developing and emerging economics (Malaysia, South Africa, Thailand, Singapore, Turkey, Taiwan, Bangladesh), rather that on already advanced countries (Germany, France, UK). Second, developing and emerging economics are mostly based on physical assets and tend to neglect the intangible assets, thus, it seems logical for VAIC researches to fail to explain a positive association among firm value and IC. Third, according to Hsu and Fang (2009), Kamukama et al. (2011), and Chen et al. (2006) the effect of IC on performance will be significant with applying the third variable as moderator or mediator variables.

Whereas, findings related to the moderation impact of DC on the relationship among IC and firm financial performance revealed that IC is not individually value relevant to firm financial performance, but it is value relevant to firm financial performance through the moderation of DC. This result is consistent with prior 
researchs by Hsu and Fang (2009), Kamukama et al. (2011), and Chen et al. (2006) in positive effect of applying moderator or mediator variable in association among IC and performance.

\section{Conclusion}

This study seeked to measure IC performance. VAIC method was employed on a sample consisting of high IC firm of Malaysia (technology sector, consumer products sector, trading and service sector, and industrial products). ROA was employed to measure the firm financial performance.

The study explored the performance of IC in high IC firms, and found out that VAIC lone does not have significant impact on firm financial performance. It is observed that there is a significant and positive association among the three dimensions of VAIC (HCE, SCE, and CEE) and firm financial performance.

DC that is defined as the orientation stable behavior of firms to renew and integrate their capabilities and resources upgrade their core capabilities in response to the dynamic market to sustain competitive advantage is used as moderating variable. The findings show that the impact of IC on firm financial performance is increased by introducing DC as moderator.

\section{References}

Bontis, N., Dragonetti, N. C., Jacobsen, K., \& Roos, G. (1999). The Knowledge Toolbox: A Review of the Tools Available to Measure and Manage Intangible Resources. European Management Journal, 17(4), 391-402. http://dx.doi.org/10.1016/S0263-2373(99)00019-5

Chan, K. H. (2009). Impact of Intellectual Capital on Organisational Performance. An Empirical Study of Companies in the Hang Seng Index (Part 1). The Learning Organization, 16(1), 4-21. http://dx.doi.org/10.1108/09696470910927641

Chen, Y. -S., Lin, M. -J. J., \& Chang, C. -H. (2006). The Influence of Intellectual Capital on New Product Development Performance - The Manufacturing Companies of Taiwan as an Example. Total Quality Management, 17(10), 1323-1339.

Edvinsson, L., \& Malone, M. S. (1997). Intellectual Capital: Realizing your Company's True Value by Finding its Hidden Brainpower. New York, NY: Harper Business.

Firer, S., \& Williams, S. M. (2003). Intellectual Capital and Traditional Measures of Corporate Performance. Journal of Intellectual Capital, 4(3), 348-360. http://dx.doi.org/10.1108/14691930310487806

Fondo, C. B., \& Wright, D. B. (2004). Intellectual Capital. (MASTER), Naval Postgraduate School, Montery, California.

Frazier, P. A., Tix, A. P., \& Barron, K. E. (2004). Testing Moderator and Mediator Effects in Counseling Psychology Research. Journal of Counseling Psychology, 51(1), 115-134. http://dx.doi.org/10.1037/ 0022-0167.51.1.115

Gan, K., \& Saleh, Z. (2008). Intellectual Capital and Corporate Performance of Technology-Intensive Companies: Malaysia Evidence. Asian Journal of Business and Accounting, 4(4), 113-130.

Hsu, L. C., \& Wang, C. H. (2012). Clarifying the Effect of Intellectual Capital on Performance: The Mediating Role of Dynamic Capability. British Journal of Management, 23(1), 179-205. http://dx.doi.org/10.1111/j. 1467-8551.2010.00718.x

Hsu, Y.-H., \& Fang, W. (2009). Intellectual Capital and New Product Development Performance: The Mediating Role of Organizational Learning Capability. Technological Forecasting \& Social Change, 76(1), 664-677. http://dx.doi.org/10.1016/j.techfore.2008.03.012

Itami, H., \& Roehl, T. W. (1991). Mobilising Invincible Assets. Cambridge: Harvard University Press.

Jaworski, B. J., \& Kohli, A. K. (1993). Market Orientation: Antecedents and Consequences. Journal of Marketing, 57(3), 53-70.

Kamukama, N., Ahiauzu, A., \& Ntayi, J. M. (2011). Competitive Advantage: Mediator of Intellectual Capital and Performance. Journal of Intellectual Capital, 12(1), 152 - 164.

Lev, B., \& Daum, J. H. (2004). The Dominance of Intangible Assets: Consequences for Enterprise Management and Corporate Reporting. Measuring Business Excellence, 8(1), 1-6. http://dx.doi.org/10.1108/13683040 410524694

Maditinos, D., Chatzoudes, D., Tsairidis, C., \& Theriou, G. (2011). The Impact of Intellectual Capital on Firms' Market Value and Financial Performance. Journal of Intellectual Capital, 12(1), 132-151. http://dx.doi.org/ 


\section{$10.1108 / 14691931111097944$}

Mouritsen, J, Bukh, P. N., Flagstad, K., Thorbjornsen, S., Rosenkrands, J. M., \& Kontis, S. (2003). Intellectual Capital Statements- the New Guideline: Danish Agency for Trade and Industry- Ministry of Trade and Industry, Denmark.

Mouritsen, J. (1998). Driving Growth: Economic Value Added Versus Intellectual Capital. Management Accounting Research, 9(4), 461-482. http://dx.doi.org/10.1006/mare.1998.0090

Nonaka, I., \& Takeuchi, H. (1995). The knowledge Creating Company. New York: Oxford University Press.

Pulic, A. (2000). VAIC - an Accounting Tool for IC Management. International Journal of Technology Management, 20(5-7), 702-714. http://dx.doi.org/10.1504/IJTM.2000.002891

Skandia. (1994). Visualising Intellectual Capital in Skandia. A Supplement to Skandia's 1994 Annual Report. Sweden: Skandia.

Sofian, S.. (2005). Intellectual Capital and Management Accounting Practices. (PhD Thesis), University of Bradford, Bradford.

Stewart, T. A. (1991). Brainpower: Intellectual Capital is Becoming Corporate America's Most Valuable Asset and can Be its Sharpest Competitive Weapon; the Challenge is to Find What you Have - and Use it. Fortune, 123(11), 44-60.

Stewart, T. A. (1997). Intellectual Capital: The New Wealth of Organizations. New York, NY: Doubleday.

Stewart, T. A. (2001). The Wealth of Knowledge: Intellectual Capital and the Twenty-First Century Organization. Westminster, MD: Doubleday.

Sullivan, P. H. (1999). Profiting from Intellectual Capital: Extracting Value from Innovation. Management, 3(2), 132-143.

Sveiby, K. E. (1989). The Invisible Balance Sheet.

Usoff, C. A., Thibodeau, J. C., \& Burnaby, P. (2002). The Importance of Intellectual Capital and its Effect on Performance Measurement Systems. Managerial Auditing Journal, 17(1), 9-15. http://dx.doi.org/10.1108/02686900210412180

Wang, C. L, \& Ahmed, P. K. (2007). Dynamic Capabilities: A Review and Research Agenda. The International Journal of Management Reviews, 9(1), 31-51. http://dx.doi.org/10.1111/j.1468-2370.2007.00201.x

Youndt, M. A. (1998). Human Resource Management System, Intellectual Capital and Organizational Performance. (PhD Thesis), Pennsylvania State University.

\section{Copyrights}

Copyright for this article is retained by the author(s), with first publication rights granted to the journal.

This is an open-access article distributed under the terms and conditions of the Creative Commons Attribution license (http://creativecommons.org/licenses/by/3.0/). 